\title{
Virulence of four entomopathogenic nematode against different stages of the Mediterranean fruit fly, Ceratitis capitata Wiedemann (Diptera: Tephritidae)
}

\author{
Mürşide Yağcl ${ }^{1 *} \mathbb{D}$, Tuğba Akdeniz Fırat ${ }^{1}$, F. Dolunay Erdoğuş ${ }^{1}$ and Müge Şahin ${ }^{2}$
}

\begin{abstract}
Background: Ceratitis capitata Wiedemann (Diptera: Tephritidae) (Mediterranean fruit fly), is one of the important polyphagous pest species in the world that harms almost all fruits causing significant yields losses. Control of this pest which is on the quarantine list of many countries is highly important. Due to the negative effects of chemical control on the environment and human health, biological control approaches have gained importance. Entomopathogenic nematodes (EPNs) are a potential biological control agent that can be used for effectively controlling the Medfly.

Results: In this study, effects of four EPNs species on larvae, pupae and adults of Medfly were investigated under laboratory conditions. Four different concentrations of EPNs species were used against each stage of the pest. It pest showed different sensitivity to different concentrations of each of the tested EPNs. High mortality rate of $94 \%$ was caused by Heterorhabditis bacteriophora (11 KG), followed by H. bacteriophora (TOK-20) with 91\%, Steinernema carpocapsae (85\%) and S. feltiae (Tokat-Emir) with $71 \%$ at highest concentration (200 IJ/larvae. The highest effect on adult mortality (100\%) was recorded by the species S. feltiae (Tokat-Emir) at the highest concentration (200 IJ/adult) in the trials, followed by H. bacteriophora (11 KG) with 92\%, H. bacteriophora (TOK-20) with 91\% and S. carpocapsae (TokatBakışlı05) with $87.37 \%$ mortality rates at the same concentrations.
\end{abstract}

Conclusions: It was determined that the EPNs tested in this study had insecticidal properties and they might be used in biological control programs against the Medfly.

Keywords: Ceraitits capitata, Biological control, Entomopathogenic nematodes, Efficiency

\section{Background}

The Mediterranean fruit fly, Ceratitis capitata Wiedemann (Diptera: Tephritidae) is one of the economic polyphagous pest species in the world (Zucchi 2001). It has been recorded in 350 hosts from 65 different families around the world. especially to temperate climate fruits and subtropical fruits, some vegetables and ornamental plants worldwide (Weems 1981; Liquido et al. 1990, 1991;

\footnotetext{
*Correspondence: myagci0645@gmail.com

${ }^{1}$ Directorate of Plant Protection Central Research Institute, Yenimahalle,

Ankara, Turkey

Full list of author information is available at the end of the article
}

Woods et al. 2005; Thomas et al. 2010). Its damages to the exported products is very important for the country's economy as this causes economic losses by affecting the yield quantity and quality (Başpınar et al. 2009). Recently, researchers are seeking for alternatives pest control tools like biological control agents. Entomopathogenic nematodes (EPNs) are obligate insect pathogens found in soil that are used as biological agents. They have a wide host range, able to kill their hosts with the help of their symbiotic bacteria within $24-48 \mathrm{~h}$, easy to mass produce, able to actively search and find their hosts, can stay alive for a long time in the absence of hosts, and do not harm the environment and humans. Studies of isolating EPNs and 
investigating their virulences have increased, and are of great importance for biological control studies (Hazır et al. 2003). Although the potentials of EPNs against many pest groups in the world have been demonstrated in laboratory and field / garden studies, there are few studies on fruit pests.

This study aimed to determine the virulences of 4 EPNs species [Steinernema carpocapsae (Weiser), S. feltiae (Filipjev) (Rhabditida: Steinernematidae) and Heterorhabditis bacteriophora Poinar (Rhabditida: Heterorhabditidae)] on the larvae, pupae and adults of the Medfly under laboratory conditions.

\section{Methods}

\section{Nematodes' source}

The EPNs species (Steinernema feltiae (Tokat-Emir), S. carpocapsae (Tokat-Bakışl105), Heterorhabditis bacteriophora (TOK-20), H. bacteriophora (11-KG) were obtained from the Plant Protection Department of Tokat Gaziosmanpaşa University, Turkey. Infective juveniles of the 4 species were reared on last instar larvae of the greater wax moth, Galleria mellonella (L.) described by Kaya and Stock (1997).

\section{Mass rearing of Galleria mellonella larvae}

Galleria mellonella's larvae were reared on a artificial diet, contained $890 \mathrm{~g}$ flour, $222 \mathrm{~g}$ dry baker's yeast, $500 \mathrm{~g}$ glycerin, $500 \mathrm{~g}$ honey, $445 \mathrm{~g}$ milk powder and $125 \mathrm{~g}$ beewax in an incubator with $16 / 8 \mathrm{~h}$ lighting set at $24-25^{\circ} \mathrm{C}$ (Mohamed and Coppel 1983).

\section{Mass rearing of entomopathogenic nematode species}

Ten last instar G. mellonella larvae were placed in small Petri dishes with lined Whatman paper. A suspension EPNs of infective juveniles inoculated the larvae. Petri dishes were placed in an incubator at $20-23^{\circ} \mathrm{C}$. Dead larvae was controlled frequently. Infective EPNs juveniles were obtained from infected G. mellonella larvae, using the "White trap" method (White 1927). Juveniles were kept in a refrigerator at $+10^{\circ} \mathrm{C}$.

\section{Rearing of the Medfly}

The stock culture of the Medfly, reared in the Entomology Laboratory, was used in the experiments. Fruit fly production was carried out in plexiglass adult cages with 50 mesh tulle on both sides in climate rooms with $25 \pm 1{ }^{\circ} \mathrm{C}, 65 \pm 5 \%$ relative humidity, and $16 \mathrm{~h}$ light and $8 \mathrm{~h}$ dark conditions. Eggs laid by mature individuals were left on large Petri dishes on artificial media made from a mixture of bran, wheat germ, yeast, hydrochloric acid and water. The last instar larvae were collected 6-8 days after the eggs laying to be used in the experiments.

\section{Experiments}

Experiments were conducted using $150 \mathrm{ml}$ plastic containers, containing the last instar larvae and pupae of the pest on soil mixture (80\% sand, $15 \%$ soil and $5 \%$ clay) sterilized at $121{ }^{\circ} \mathrm{C}$ (Chen et al. 1995). Five-to 7-day-old pupae were used in the experiments. In adult trials, EPNs were applied by placing Whatman paper on the bottom of $150 \mathrm{ml}$ plastic containers and a piece of cotton soaked in sugar melted water was also left in each container. Four concentrations $(0,50,100,200$ IJs/C. capitata stages) for each nematode species were tested against both late instar larvae, pupae and adults of C. capitata. Trials had 10 replications of each concentration and 5 individuals per repeat (50 individuals in total). After placing the 5 individuals of the pest in each plastic container, the nematodes were applied by a pipette. Only distilled water and sugar melted water were provide as food for the adults in control group. All the trials were repeated twice, on different dates, and the set up was incubated at $25^{\circ} \mathrm{C}$ under $16 \mathrm{~h}$ dark and $8 \mathrm{~h}$ light climatic room conditions. Mortality rates of adults and larvae were calculated 5 days after the inoculation, while pupae were calculated 10 days later. Dead medfly larvae, pupae and adults were collected and placed in the White trap method. About one week later, EPNs emerged from insect cadavers and were examined under a stereomicroscope.

\section{Statistical analyses}

In experiments, all data were analyzed by statistical program JMP 7. Analyses were done using one-way ANOVA and used "LSMeans Student's t test" for finding the variety in the effects of different nematode species and concentrations on Medfly.

\section{Results}

Data were evaluated 5 days after EPNs inoculation of the medfly's larvae and adults. Pupal data were evaluated after 10 days. Statistically, both parameters (species and concentrations) were found to be significant. Mortality rates of the last instar larvae of the medfly increased directly as the concentration increased in case of all EPNs species $(p<0.001)$.

\section{Virulence of EPN species at different concentrations against Ceratitis capitata last instar larvae}

It was observed that all the applications against the Medfly last instar larvae were quite effective than the controls. High mortality rates of all EPNs species against the last instar larvae of the Medfly were recorded at $200 \mathrm{IJS} /$ larva (at high concentration). High mortality rate (94\%) was reported in case of $H$. bacteriophora (11 KG) isolate, followed by $H$. bacteriophora (TOK-20) with (91\%), $S$. 
carpocapsae (Tokat-Bakışlı5) with (85\%), and S. feltiae (Tokat-Emir) with $(71 \%)$ at $200 \mathrm{IJs} /$ larva. Mortality rates at the $25 \mathrm{IJs} /$ larva concentration were found close to those of $200 \mathrm{IJs} /$ larva. At this concentration, the highest deaths were recorded by $H$. bacteriophora $(11 \mathrm{KG})$ isolate with (88\%), followed by $H$. bacteriophora (TOK-20) with (87\%), S. carpocapsae (Tokat-Bakışlı5) with $(85,88 \%)$, and S. feltiae (Tokat-Emir) with (71\%). At $100 \mathrm{IJs} /$ larva concentration, $H$. bacteriophora (11 KG) was found to cause the highest mortality rate with (88\%). In addition, the mortality rates in other species were determined as (87\%) for $H$. bacteriophora (TOK-20), (85.88\%) for $S$. carpocapsae (Tokat-Bakışl105), and (71\%) for S. feltiae (Tokat-Emir) at concentration of $100 \mathrm{IJs} /$ larva. The lowest mortality rate in the last instar larvae of the pest was by $50 \mathrm{IJs} / C$. capitata larva. The mortality rates at this concentration $50 \mathrm{IJs} /$ larva were in $\mathrm{H}$. bacteriophora (11 KG) isolate with (87\%), followed by $H$. bacteriophora (TOK$20)$ with (84\%), S. feltiae (Tokat-Emir) with (66\%) and $S$. carpocapsae (Tokat-Bakışl105) with (64\%) (Table 1).

\section{Virulence of EPN species at different concentrations against pupae of $C$. capitata}

The pupae were evaluated at 10 days after from the application. While the difference between the concentrations was significant, the difference between the species was not statistically significant. In pupal stage trials, applications were found to be effective than the control. The highest mortality rate was found at 200 IJs/pupa concetrations for all EPNs nemetode species.
S. carpocapsae (Tokat-Bakışl105) isolate with (52\%), followed by H. bacteriophora (11 KG) with (51\%), H. bacteriophora (TOK-20) with (49\%), S. feltiae (Tokat-Emir) with (43\%) at $200 \mathrm{IJs} /$ pupa (Table 2). The least mortality rate was calculated $50 \mathrm{IJs} /$ pupa concetrations to all nematode species.

\section{Virulence of EPN species at different concentrations against adults of Ceratitis capitata}

In all trials and concentrations against adults of the pest were found to be more effective than controls. In addition, as the concentration increased in all EPNs species used and the mortality rate of the adult individuals increased in direct proportion $(p<0.001)$.

The highest mortality rate $(100 \%)$ detected at $200 \mathrm{IJs} /$ adult concentration against the adults, was caused by S. feltiae (Tokat-Emir), followed by $H$. bacteriophora (11 KG) with (92\%), H. bacteriophora (TOK-20) with (91\%), and S. carpocapsae (Perspective 05) with (87.37\%). At $100 \mathrm{IJs} /$ adult concentration, the highest deaths were observed in S. feltiae (Tokat-Emir) with (89.47\%), followed by $H$. bacteriophora (11 KG) with (88\%), H. bacteriophora (TOC-20) with (86\%), and (61.05\%) for $S$. carpocapsae (Bakisli 05). The lowest mortality rate in adults of $C$. capitata was at $50 \mathrm{IJs} /$ adult concentration. The mortality rates at $50 \mathrm{IJs} /$ adult were $(84 \%)$ with $H$. bacteriophora (TOC-20), (83\%) with S. feltiae (TokatEmir), (78\%) with S. carpocapsae (Bakisli 05) and (75.56\%) with H. bacteriophora (11 KG) isolates (Table 3).

Table 1 Effect of nematode species and concentrations on mortality rate of Mediterranean fruit fly larvae

\begin{tabular}{|c|c|c|c|c|}
\hline \multirow[t]{2}{*}{ Nematode species } & \multicolumn{4}{|c|}{ Concentrations (IJs/larvae) } \\
\hline & Control & $501 \mathrm{~J} / C$. capitata & 100IJ/C. capitata & 200IJ/C. capitata \\
\hline Heterorhabditis bacteriophora (11 KG) & $12.00^{\mathrm{d}}$ & $87.00^{\mathrm{ab}}$ & $88.00^{\mathrm{ab}}$ & $94.00^{\mathrm{a}}$ \\
\hline H. bacteriophora (TOK-20) & $9.00^{d}$ & $84.00^{\mathrm{b}}$ & $87.00^{\mathrm{ab}}$ & $91.00^{\mathrm{ab}}$ \\
\hline Steinernema carpocapsae (Tokat-Bakışı05) & $12.00^{d}$ & $64.00^{c}$ & $85.88^{\mathrm{ab}}$ & $85.00^{\mathrm{ab}}$ \\
\hline S. feltiae (Tokat-Emir) & $10.00^{d}$ & $66.00^{c}$ & $71.00^{c}$ & $71.00^{c}$ \\
\hline
\end{tabular}

CV: 0.23 , LSD: 9.10

Means followed by the same letter are not statistically different according to the Duncan test $(P \leq 0.05)$

Table 2 Effect of nematode species and concentrations on mortality rates of Medfly pupae

\begin{tabular}{|c|c|c|c|c|}
\hline \multirow[t]{2}{*}{ Nematode species } & \multicolumn{4}{|c|}{ Concentrations (IJs/pupa) } \\
\hline & Control & 50IJ/C. capitata & 100IJ/C. capitata & 200IJ/C. capitata \\
\hline Heterorhabditis bacteriophora (11 KG) & $10.00^{d}$ & $32.00^{c}$ & $42.00^{b}$ & $51.00^{\mathrm{a}}$ \\
\hline $\begin{array}{l}\text { H. bacteriophora } \\
(\mathrm{TOK}-20)\end{array}$ & $6.00^{d}$ & $26.00^{c}$ & $40.00^{b}$ & $49.00^{\mathrm{a}}$ \\
\hline Steinernema carpocapsae (Tokat-Bakışlı05) & $5.00^{d}$ & $32.00^{c}$ & $42.00^{b}$ & $52.00^{\mathrm{a}}$ \\
\hline S. feltiae (Tokat-Emir) & $12.00^{\mathrm{d}}$ & $25.00^{c}$ & $32.00^{b}$ & $43.00^{\mathrm{a}}$ \\
\hline
\end{tabular}

CV: 0.56 , LSD: 5.47

Means followed by the same letter are not statistically different according to the Duncan test $(P \leq 0.05)$ 
Table 3 Effect of nematode species and concentrations on mortality rate of Medfly's adults

\begin{tabular}{lcccc}
\hline Nematode species & \multicolumn{3}{l}{ Concentrations (IJs/adult) } \\
\cline { 2 - 5 } & Control & $\mathbf{5 0 I J / C . ~ c a p i t a t a ~}$ & 100IJ/C. capitata & 200IJ/C. capitata \\
\hline Heterorhabditis bacteriophora (11 KG) & $6.00^{\mathrm{f}}$ & $75.56^{\mathrm{d}}$ & $89.00^{\mathrm{b}}$ & $92.00^{\mathrm{ab}}$ \\
H. bacteriophora (TOK-20) & $7.00^{\mathrm{f}}$ & $84.00^{\mathrm{bd}}$ & $86.00^{\mathrm{bc}}$ & $91.00^{\mathrm{ab}}$ \\
Steinernema carpocapsae (Tokat-Bakış|105) & $10.00^{\mathrm{f}}$ & $78.89^{\mathrm{cd}}$ & $61.05^{\mathrm{e}}$ & $87.37^{\mathrm{bc}}$ \\
S. feltiae (Tokat-Emir) & $9.00^{\mathrm{f}}$ & $83.00^{\mathrm{bd}}$ & $89.47^{\mathrm{b}}$ & $100^{\mathrm{a}}$ \\
\hline
\end{tabular}

CV 0.23, LSD: 9.42

Means followed by the same letter are not statistically different according to the Duncan test $(P \leq 0.05)$

\section{Discussion}

C. capitata is a highly invasive species. It has a high dispersive ability, a very large host range. It has a high economic impact, affecting production, control costs and market access. (Malacrida et al. 2007). Several studies have been carried out to evaluate the efficiency of steinernematid and heterorhabditid nematodes against C. capitata. Karagöz et al. (2009) showed that Steinernema weiseri, S. feltiae, S. carpocapsae and 2 strains of Heterorhabditis bacteriophora, isolated from Turkish soils, were very effective against larvae of the Medfly. On the other hand, Minas et al. (2016) tested 8 strains, 6 of them were native to Brazil, in sand columns against 3rd instar larvae (L3) of C. capitata. The highest mean mortality values reached by Heterorhabditis sp. LPP17, Heterorhabditis sp. LPP14 and H. baujardi LPP7 were 98.5, 95.5 and 90\%, respectively. In another study Malan and Manrakhan (2009) $H$. bacteriophora, $H$. zealandica and S. khoisanae to infect pupariating larvae, pupae and adults of C. capitata and Ceratitis rosa was investigated in laboratory bioassays. Significantly more larvae of $C$. capitata were infected by $H$. bacteriophora. For C. rosa, the highest infectivity of larvae was obtained by $H$. zealandica. In contrast, adults of both species were highly infected by $S$. khoisanae. Pupariating larvae and adult flies were susceptible to all nematode infection, with no infection was recorded for the pupae. Rohde et al. (2020) reported that Steinernema carpocapsae ALL and Heterorhabditis amazonensis JPM4 were found effective in controlling larvae and pupae of $C$. capitata. Both nematodes killed C. capitata larvae and pupae, but $S$. carpocapsae ALL was the most effective. The all evaluated concentrations of $H$. amazonensis JPM4 nematodes also killed C. capitata larvae and pupae at different ages. $H$. amazonenses JPM4 nematodes effective with 28 to $54 \%$ for young pupae and 11 to $44 \%$ for old pupae. In Morocco, Mokrini et al. (2020) evaluated the efficiency of EPN strains against $C$. capitata. In laboratory assays, S. feltiae-SFMOR9, S. feltiae-SF-MOR10 and H. bacteriophora-HBMOR7 strains showed significantly higher infectivity and penetration rates than other strains. S. feltiae-SFMOR9 caused the highest larval mortality rate $(80 \%)$ at 50 infective juveniles (IJs). Gazit et al. (2010) tested 12 EPN strains. Steinernema riobrave Texas (Sr TX) and Heterorhabditis sp. IS-5 (H IS-5) showed high activity and induced $>80 \%$ mortality. Six EPN strains showed limited activity ( $>30 \%$ mortality), and 4 strains had no effect ( $<20 \%$ mortality). Soliman et al. (2014) reported that the ability of $H$. bacteriophora infective juveniles to infect last insar larvae of B. zonata and C. capitata was more than $S$. riobrave.

\section{Conclusions}

Four EPNs species were found very effective against the C. capitata last instar larvae and adults. S. feltiae (TokatEmir) provided to be the best candidate among the other EPN species to control Medfly larvae, while $H$. bacteriophora (11 KG) was the best among the other EPN species to control the adults. However, the 4 isolates could all be used for the control of C. capitata biological control program in orchards. However, more field studies are needed to be conducted.

\section{Abbreviations}

EPNs: Entomopathogenic nematodes; IJs: Infective juveniles; C. capitata Ceratitis capitata: Cydia pomonella; H. bacteriophora: Heterorhabditis bacteriophora; S. carpocapsae: Steinernema carpocapsae; S. fertilae: Steinernema feltiae; G. mellonella: Galleria mellonella; Medfly: Mediterranean fruit fly.

\section{Acknowledgements \\ We would like to extend our thanks to Professor Illker KEPENEKCi for providing entomopathogen nematode isolates.}

\section{Authors' contributions}

M.Y participated in setting the work planning and executing the experimental work. T.A.F rearing C. capitata larvae and adults participated in experimental studies. F.D.E and M.Y mass rearing entomopathogenic nematodes and participated in experimental studies. M.Ş analyzed the all data (statistical analyses) in study. All authors read and approved the final manuscript.

\section{Funding}

This study is funded by Republıc of Turkey Ministry of Agriculture And Forestry General Directorate of Agricultural Research and Policies co-partner with Vefa 
Illaç Sanayi ve Tic. A.Ş. Company. These funder provided all chemicals and materials used in experimental bioassay.

\section{Availability of data and materials}

The datasets used and analyzed during the current study are available from the corresponding author on reasonable request.

\section{Declarations}

Ethics approval and consent to participate Not applicable.

\section{Consent for publication}

Not applicable.

\section{Competing interests}

The authors declare that they have no competing interest.

\section{Author details}

${ }^{1}$ Directorate of Plant Protection Central Research Institute, Yenimahalle, Ankara, Turkey. ${ }^{2}$ Aegean Agricultural Research Institute, Menemen, Izmir, Turkey.

Received: 24 June 2021 Accepted: 18 September 2021

Published online: 22 September 2021

\section{References}

Başpınar H, Çakmak I, Koçlu T, Başpınar N (2009) Aydın Illi Meyve Bahçelerinde Akdeniz Meyve Sineği Ceratitis capitata Wiedemann (Diptera: Tephritidae)'nın Biyo-ekolojisi, Zararı, Yayılışı ve Turunçgil Bahçeleri Üzerindeki Çalışmaları. ToVAG 105017, 56

Chen SY, Dickson DW, Mitchell DJ (1995) Effects of soil treatments on the survival of soil microorganisms. J Nematol 27(4S):661-663

Gazit Y, Rossler Y, Glazer T (2010) Evaluation of entomopathogenic nematodes for the control of Mediterranean fruit fly (Diptera: Tephritidae). Biocontrol Science and Technology, pp 157-164. https://doi.org/10.1080/09583 150029297

Hazır S, Kaya HK, Stock SP, Keskin N (2003) Entomopathogenic Nematodes (Steinernematidae and Heterorhabditidae) for Biological Control of Soil Pests. Turk J Biol 27:181-202

Karagöz M, Gulcu B, Hazir C, Kaya HK, Hazir S (2009) Biological control potential of Turkish entomopathogenic nematodes against the Mediterranean fruit fly Ceratitis capitata. Phytoparasitica 37:153-159. https://doi.org/10.1007/ s12600-008-0020-5

Kaya HK, Stock SP (1997) Techniques in insect nematology. In: Lacey L (ed) Manual of techniques in insect pathology. Academic Press, San Diego, pp 281-324

Liquido NJ, Cunningham R, Nakagawa S (1990) Host plants of Mediterranean FruitFly on the Island of Hawaii. J Econ Entomol 83(5):1863-1878
Liquido NJ, Shinoda LA, Cunningham RT (1991) Host Plants of the Mediterranean Fruit Fly (Diptera Tephritidae): an annotated World review. Entomological Society of America. Miscellaneous Publications, No. 77

Malacrida AR, Gomulski LM, Bonizzoni M, Bertin S, Gasperi G, Guglielmino CR (2007) Globalization and fruit fly invasion and expansion: the medfly paradigm. Genetica 131(1):1-9

Malan AP, Manrakhan A (2009) Susceptibility of the Mediterranean fruit fly(Ceratitis capitata) and Natal fruit fly (Ceratitis rosa) to entomopathogenic nematodes. J Invertebr Pathol 100:47-49

Minas RS, Souza RM, Dolinski C, Carvalho RS, Burla RS (2016) Potential ofentomopathogenic nematodes (Rhabditida: Heterorhabditidae) to control Mediterranean fruit fly (Diptera: Tephritidae) soil stages. Nematoda 3:e02016

Mohamed MA, Coppel HC (1983) Mass rearing of the greater wax moth Galleria melonella (Lepidoptera: Galleridae) for small-scale laboratory. Great Lakes Entomol 16(4):139-141

Mokrini F, Laasli SE, Youssef B, Joutei AB, Blenzar A, Lakhal H, Sbaghi M, Imren M, Özer G, Paulitz T, Lahlali R, Dababat A (2020) Potential of Moroccan entomopathogenic nematodes for the control of the Mediterranean fruit fly Ceratitis capitata Wiedemann (Diptera: Tephritidae. Scientific reports 10, Article number: 19204. doi:https://doi.org/10.1038/ s41598-020-76170-7

Rohde C, Mertz NR, Junior AM (2020) Entomopathogenic nematodes on control of mediterranean fruit fly (Dıptera: Tephrıtıdae). Revista Caatinga 33(4):974-984. https://doi.org/10.1590/1983-21252020v33n412rc

Soliman NA, Ibrahim AA, El-Deen MM, Shams Ramadan NF, Farag SR (2014) Entomopathogenic nematodes and fungi as bioControl agents for the peach fruit fly, Bactrocera zonata (Saunders) and theMediterranean fruit fly, Ceratitis capitata (Wiedemann) soil borne-stages. Egypt. J. Biol. Pest Co.2014,24,497-502

Thomas MC, Heppner JB, Woodruff RE, Weems HV, Steck GJ, Fasulo TR (2010) Mediterranean Fruit Fly, Ceratitis capitata (Wiedemann) (Insecta: Diptera: Tephritidae). University of Florida, IFAS Extension, EENY-214

Weems HV (1981) Mediterranean Fruit Fly, Ceratitis capitata (Wiedemann) (Diptera: Tephritidae). Plant Industry, Entomology Circular, Florida Department of Agriculture, 230: pp. 8

White GF (1927) A method for obtaining infective nematode larvae from cultures. Science 66:302-330

Woods B, Lacey I, Brockway C, Johnstone C (2005) Hosts of Mediterranean Fruit Fly Ceratitis capitata (Wiedemann) (Diptera: Tephritidae) From Broome and the Broome Peninsula, Western Australia. Australian J Entomol 44(4):437-441

Zucchi RA (2001) Mosca-do-mediterrâneo, Ceratitis capitata (Diptera:Tephritidae). In Vilela, E.F.; Zucchi, R.A.; Cantor, F. (Eds.). Pragas introduzidas no Brasil. Ribeirão Preto: Holos Editora, pp 15-22

\section{Publisher's Note}

Springer Nature remains neutral with regard to jurisdictional claims in published maps and institutional affiliations.

\section{Submit your manuscript to a SpringerOpen ${ }^{\circ}$ journal and benefit from:}

- Convenient online submission

- Rigorous peer review

- Open access: articles freely available online

- High visibility within the field

Retaining the copyright to your article

Submit your next manuscript at springeropen.com 